\title{
Tax Holiday and Foreign Direct Investment In Indonesia
}

\section{EcceS: \\ Economics Social and Development Studies}

\author{
Liza Herdiyati ${ }^{1}$, \\ Setyo Tri Wahyudi ${ }^{2}$ \\ ${ }^{1,2}$ Department of Economics, Faculty of Economics and Business, University of Brawijaya \\ $1,2 \mathrm{Jl}$. MT. Haryono 165 Malang, Indonesia \\ E-mail : lizaherdiyati@student.ub.ac.id ${ }^{1}$, setyo.tw@ub.ac.id ${ }^{2}$
}

(Article history) Received: 2020-10-30, Revised: 2020-12-11, Accepted: 2020-12-17,

Available online: 2020-12-26, DOI: https://doi.org/10.24252/ecc.v7i2.16811

http://journal.uin-alauddin.ac.id/index.php/ecc/index

\section{Abstract: Tax Holiday and Foreign Direct Investment in Indonesia}

Foreign Direct Investment Inflows is important aspect of promoting economic growth and decreasing the unemployment rate. One of investment incentive applied in Indonesia is Tax Holiday. Meanwhile, research on tax holiday and their relation to foreign investment in Indonesia is still rare. This paper is aimed to measure the impact of Tax Holiday toward Foreign Direct Investment inflows in Indonesia. So, this study also compares the impact of tax holidays on 18 industries in Indonesia. The research found that the Tax Holiday incentive did not reach the expected target. Only 9 out of 18 business sectors affected by this policy, accounted for only $50 \%$ of its industrial target. The government's role is highly expected to evaluate the target of Tax Holiday, for example giving priority and adding incentives for industrial sectors that are clearly affected by the tax holiday policy.

Keywords: Foreign Direct Investment; Investment Incentive; Tax Holiday.

\section{INTRODUCTION}

Foreign Direct Investment (FDI) has an essential role in the economy of a country. According to Kok dan Ersoy (2009), PMA has an effect on income, production, employment, economic growth, and general development and welfare in the host country. Apart from 
Liza Herdiyati, Setyo Tri Wahyudi, Tax Holiday and Foreign Direct Investment In Indonesia.

bringing in capital/capital, FDI also facilitates the transfer of technology, practice, and managerial and organizational skills, and facilitates access to international trade (UNCTAD, 2000). The size and relative stability of FDI make it the most important source of external financing for developing countries than portfolio investment, remittances, Official Development Assistance (ODA), and other investments (UNCTAD, 2019).

The presence of PMA in Indonesia is one solution to reducing the unemployment rate in Indonesia. Compared to other ASEAN-5 countries (Singapore, Malaysia, Thailand, and the Philippines), the unemployment rate in Indonesia is the highest with $4.3 \%$, followed by Singapore and Malaysia with 3.8\% and 3.4\% (World Bank, 2018). The increase in the inflow of FDI in Indonesia is an essential factor in supporting sustainable economic growth, particularly in overcoming unemployment in Indonesia. In the second Quarter of 2019 (April to June 2019), investment in Indonesia absorbed as many as 255,314 workers, with the proportion of Foreign Direct Investment absorbing 114,161 workers and Domestic Investment (PMDN) absorbing 141,153 worker (BKPM, 2018).

Figure 1. Unemployment Rate in ASEAN-5 Countries 2010-2019

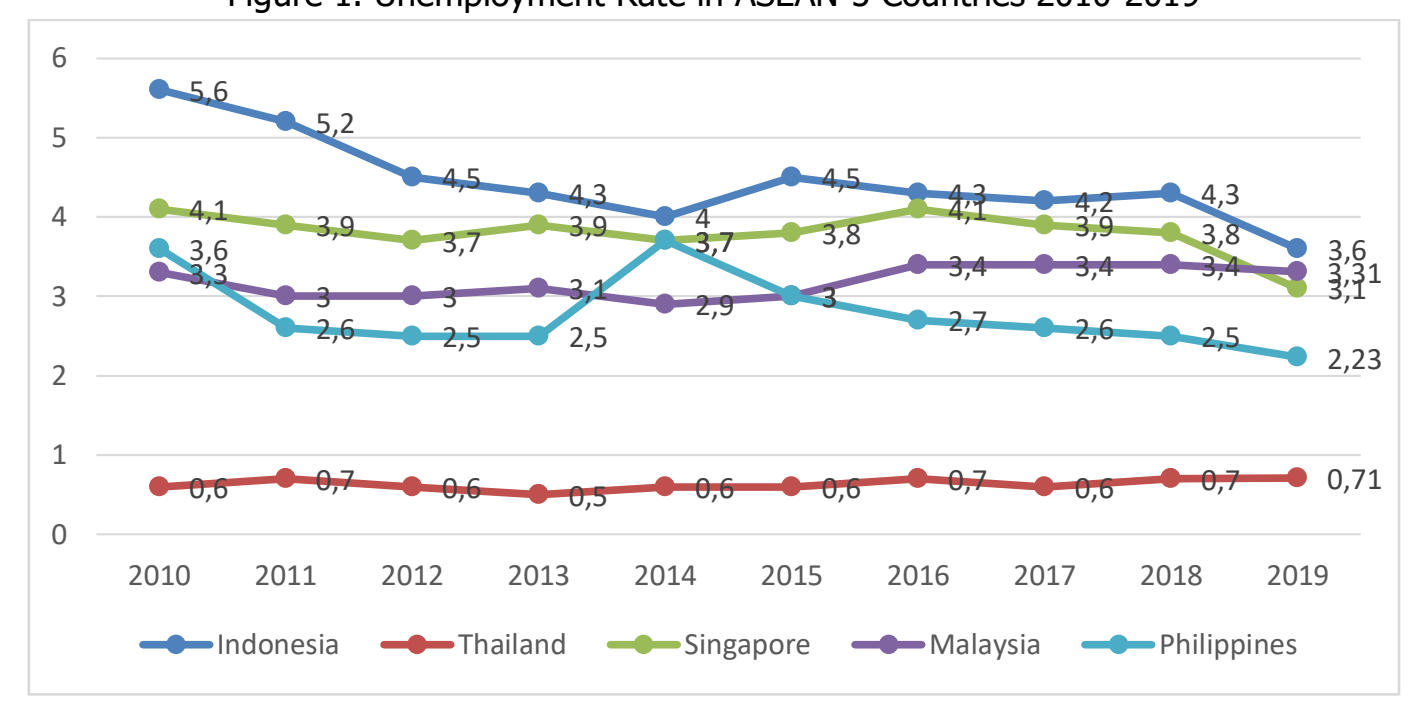

Source: Data proceed from World Bank, 2020

In connection with the trade war between the United States and China since 2018, Indonesia is expected to take advantage of this situation. Every country competes to make its territory an investment destination country, including developing countries like Indonesia. The Indonesian government has carried out various investment promotions to attract foreign investors interested in diverting their investment locations from America or China. Investment incentives in the form of fiscal were expanded and improved. However, they were still deemed to have failed in attracting FDI inflows to Indonesia. It is evidenced that 
Indonesia was not chosen as the investment destination country of the 33 companies that relocated their investment from China. Twenty-three companies chose Vietnam as their business destination, and ten other companies chose Malaysia, Cambodia, and Thailand as their new business locations.

The amount of FDI inflows to Indonesia has been relatively constant at $2-2.5 \%$ of total GDP in Indonesia over the past decade. In 2016 there was a significant decrease to $0.49 \%$, possibly due to the global economy's instability, which resulted in many countries choosing to invest in developed countries rather than developing countries and transition economies. In 2017, FDI inflows in Indonesia stabilized towards $2.02 \%$.

Figure 2. The Inflow of Foreign Direct Investment in Indonesia, 2004 s.d. 2019

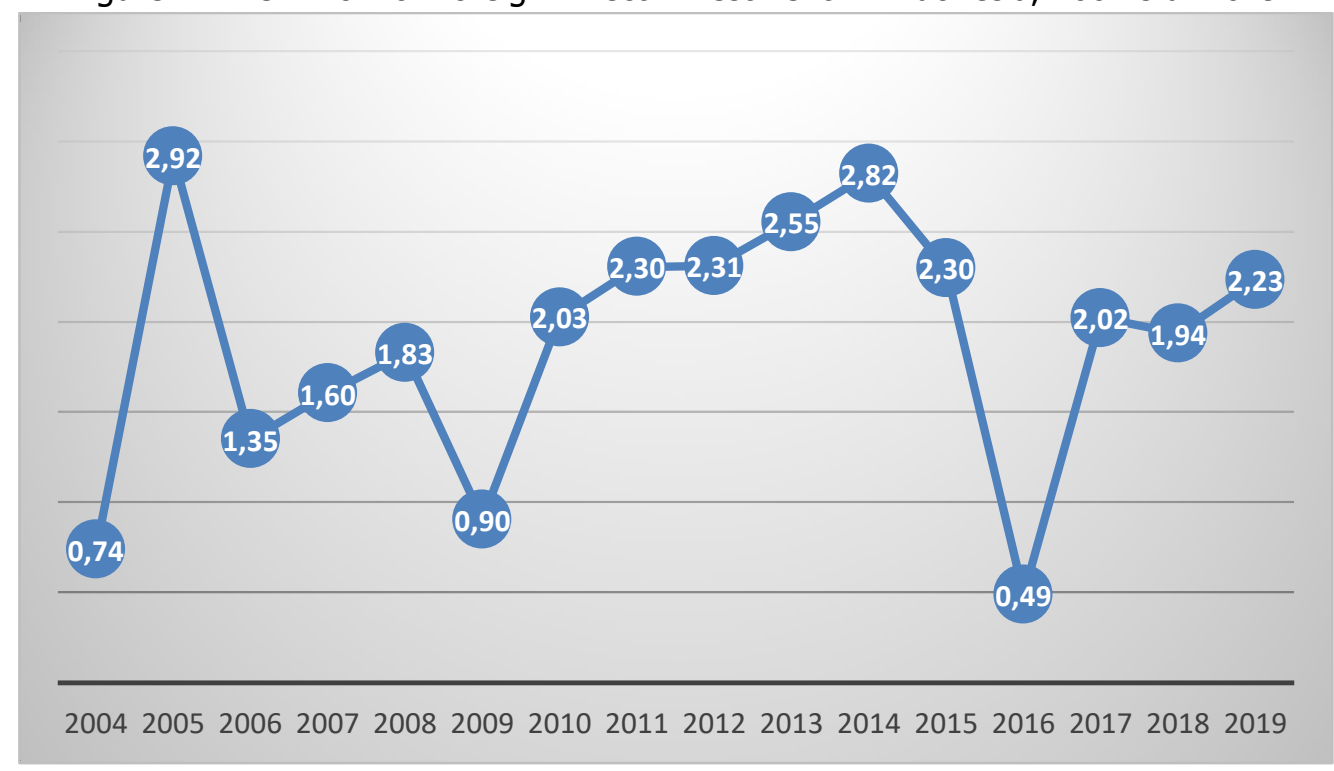

Source: Data proceed from BKPM, 2020

In the last few decades, many countries, especially developing countries, have made efforts to increase the attractiveness of foreign direct investment in host countries. The steps taken include economic liberalization, guaranteeing profit repatriation, infrastructure provision, low labor wages, and tax incentives. Among these efforts, the provision of tax incentives is the most common because it can provide facilities directly to investors and place them in strategic positions, hoping that investors can improve their performance and continue to invest in the country (Abille et al. 2020). 
Figure 3. FDI inflows to Indonesia from 2005-2019

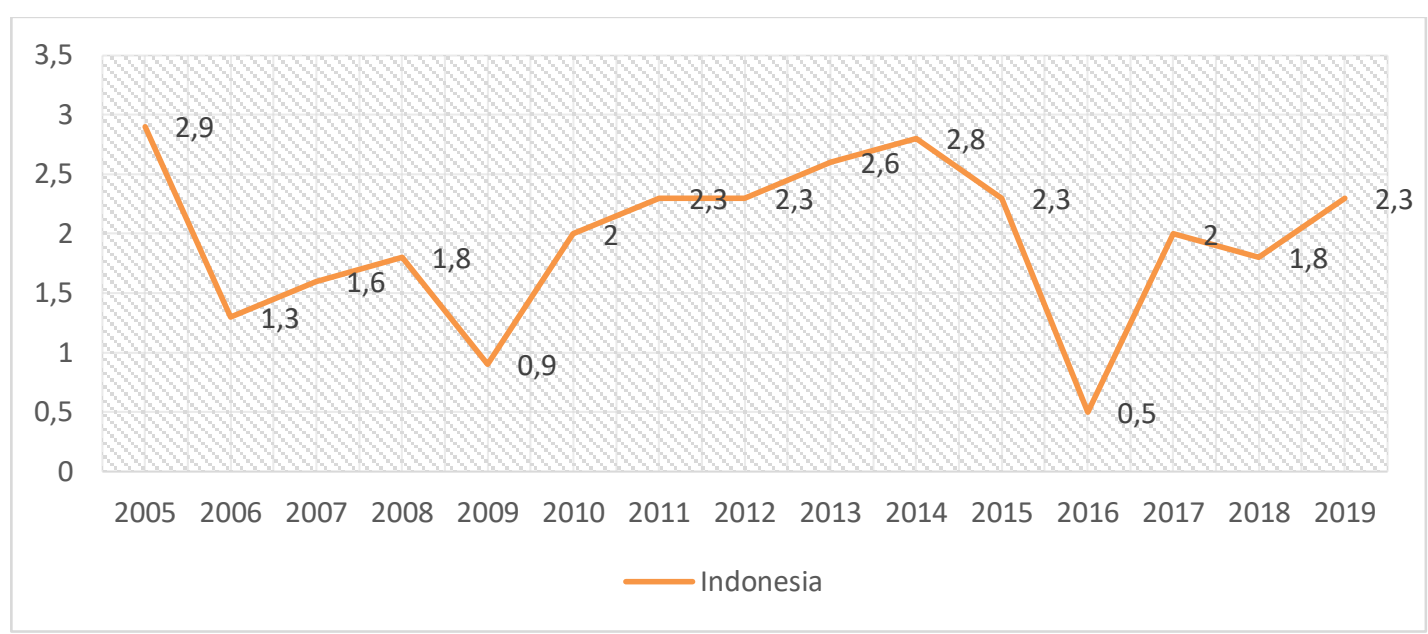

Source: Data proceed from World Bank, 2020

World Bank data on FDI inflows to Indonesia illustrate that FDI reached the highest amount in 2005 over the past two decades, at 2.9 percent of GDP. However, this was followed by a decline in the next few years. In 2010, FDI inflows began to increase until 2014 to 2.8 percent of GDP, and in 2016 decreased to 0.5 percent.

Based on the classification of the business sector, the flow of FDI to Indonesia during the last three years (2017 - 2019) was dominated by five business fields, namely mining; Food industry; Electricity, Gas \& Water; Transportation, Storage \& Communication; and Real Estate, Industrial Estates \& Business Activities. Meanwhile, Forestry and Fisheries have the lowest number of FDI, both in terms of the number of projects and the amount of investment in million US dollars. Judging from the number of projects and the size of the investment, the dominant business sector can prioritize the government to improve and maintain.

The development of investment policy has a significant influence on FDI. In 2018, 55 countries introduced their new national investment policies; At least 112 regulations (the highest number for two decades) have been implemented to influence FDI inflows (UNCTAD, 2019). The majority of investment policy reform proposals are directed towards liberalization and investment encouragement. In 2015, 85 percent of interventions in the form of investment incentives were considered beneficial for investors, and developing countries in Asia were the most involved in liberalizing investment in various sectors (UNCTAD, 2016). In general, investment promotion and facilitation have always operated 
side by side. Each has two distinct types of operations, namely: by promoting location as an investment destination; and by making it easier for investors to organize or expand their investments and to carry out their day-to-day business in the host country (UNCTAD, 2016).

Figure 4. FDI Inflows to Indonesia by Business Sector 2017-2019

\begin{tabular}{|c|c|c|c|c|c|c|}
\hline \multirow[b]{2}{*}{ Business fields } & \multicolumn{2}{|c|}{2017} & \multicolumn{2}{|c|}{2018} & \multicolumn{2}{|c|}{2019} \\
\hline & Project & $\begin{array}{c}\text { Investment } \\
\text { (Million US } \\
\text { Dollar) }\end{array}$ & Project & $\begin{array}{l}\text { Investment } \\
\text { (Million US } \\
\text { Dollar) }\end{array}$ & Project & $\begin{array}{c}\text { Investment } \\
\text { (Million US } \\
\text { Dollar) }\end{array}$ \\
\hline $\begin{array}{l}\text { Food Crops, Plantation and Animal } \\
\text { Husbandry }\end{array}$ & 770 & $1.592,8$ & 660 & $1.721,2$ & 969 & 946,9 \\
\hline Forestry & 82 & 48,1 & 82 & 43,2 & 113 & 36,3 \\
\hline Fishery & 117 & 59,3 & 105 & 24,3 & 173 & 54,1 \\
\hline Mining & 729 & $4.375,9$ & 606 & $3.038,6$ & 758 & $2.256,3$ \\
\hline Food industry & 1.649 & $1.970,3$ & 1.377 & $1.307,3$ & 1.848 & $1.272,2$ \\
\hline Textile industry & 834 & 372,2 & 715 & 305,4 & 897 & 238,9 \\
\hline Leather Goods \& Footwear Industry & 300 & 368,9 & 248 & 243,6 & 342 & 188,3 \\
\hline Wood industry & 223 & 395,7 & 197 & 276,0 & 281 & 95,0 \\
\hline Paper and Printing Industry & 388 & 606,2 & 326 & 668,1 & 409 & 446,1 \\
\hline Chemical and Pharmaceutical Industry & 1.135 & $2.578,5$ & 1.001 & $1.938,3$ & 1.282 & $1.486,1$ \\
\hline Rubber and Plastics Industry & 733 & 633,1 & 663 & 447,0 & 804 & 291,6 \\
\hline Non-Metallic Mineral Industry & 341 & 671,7 & 253 & 456,3 & 281 & 475,0 \\
\hline $\begin{array}{l}\text { Non-Mechanical \& Electronic Metal } \\
\text { Industry }\end{array}$ & 904 & $2.969,3$ & 767 & $2.219,1$ & 983 & $3.558,7$ \\
\hline $\begin{array}{l}\text { Medical Equipment \& Optical } \\
\text { Instruments, Watches and Watches, } \\
\text { Machinery and Electronic Industries } \\
\text { Motor Vehicles \& Transportation } \\
\text { Equipment Equipment Other Industries }\end{array}$ & 1.148 & 817,5 & 971 & $1.341,1$ & 1.087 & 499,8 \\
\hline Electricity, Gas \& Water & 945 & $1.271,4$ & 823 & 971,3 & 960 & 754,0 \\
\hline Construction & 558 & 504,4 & 502 & 174,0 & 700 & 245,3 \\
\hline Trade \& Repair & 587 & $4.241,4$ & 515 & $4.383,8$ & 646 & $5.921,2$ \\
\hline $\begin{array}{l}\text { Hotel \& Restaurant Transportation, } \\
\text { Storage \& Communication }\end{array}$ & 460 & 224,7 & 301 & 248,1 & 430 & 161,6 \\
\hline $\begin{array}{l}\text { Real Estate, Industrial Estates \& } \\
\text { Business Activities Other Services }\end{array}$ & 6.915 & $1.294,1$ & 5.059 & 609,3 & 6.467 & 421,2 \\
\hline Fishery & 2.167 & $1.089,6$ & 2.188 & 868,9 & 3.704 & 625,9 \\
\hline Mining & 670 & $1.899,6$ & 578 & $3.027,2$ & 805 & $4.727,8$ \\
\hline Food industry & 1.012 & $3.239,6$ & 941 & $4.302,7$ & 1.308 & $2.888,5$ \\
\hline Textile industry & 3.590 & $1.015,3$ & 3.094 & 692,9 & 5.107 & 617,9 \\
\hline Total & 26.257 & $32.239,8$ & 21.972 & $29.307,9$ & 30.354 & $28.208,8$ \\
\hline
\end{tabular}

Source: Data proceed from BKPM, 2020

The Indonesian government has also demonstrated its efforts to facilitate and promote FDI by simplifying investment licensing using information and communication 
Liza Herdiyati, Setyo Tri Wahyudi, Tax Holiday and Foreign Direct Investment In Indonesia.

technology. In 2018, the Online Single Submission (OSS) program was implemented to reduce business registration time and costs. The Indonesian government has also lowered the minimum equity requirement for foreign investors to use the OSS portal from IDR 10 billion to IDR 2.5 billion. It also removes approval requirements for several business transactions involving foreign investors, such as changes in shareholders, changes in capital structure, and conversion of domestic companies into foreign companies. Tax incentives in the form of Tax Holidays and several new policies have been issued to attract foreign companies to invest in Indonesia. The investment facilitation and promotion carried out by the Indonesian government is considered quite successful. According to the World Investment Report 2019 by UNCTAD (2019), in 2018, Indonesia was one of the largest FDI recipients among developing countries in Asia, along with China, Hong Kong, Singapore, and India. FDI inflows to Indonesia in 2018 grew mainly due to intra-ASEAN investment, especially from Singapore. There was also a significant contribution from Chinese and Japanese investment. Other major infrastructure projects involving foreign Multinational Companies (MNE), such as the new Jakarta Light Rail Transit segment, were completed in 2018. New Special Economic Zones (KEK), such as Galang Batang and Sei Mangkel, also contribute to foreign investment inflows, both in the construction phase and attracting new investment in the area.

Given the vital role of FDI in inclusive growth, various investment policies have been implemented to increase the inflow of FDI. At the global level, organizations such as the WTO and the IMF are trying to increase the inflow of FDI by reducing the transfer of funds (Saini and Singhania, 2018). Meanwhile, at the national level, the Government provides convenience in investing by issuing investment facilities such as tax incentive policies. Tax incentives include a reduced tax on profits/profits, tax holiday, accounting regulations, reduced tariffs on imported equipment/components / raw materials, or increased tariffs to protect the domestic market for investment projects import substitutes (UNCTAD, 2000).

Meanwhile, at the national level, the Government provides convenience in investing by issuing investment facilities such as tax incentive policies. Tax incentives include a reduced tax on profits/profits, tax holiday, accounting regulations, reduced tariffs on imported equipment/components / raw materials, or increased tariffs to protect the domestic market for investment projects import substitutes. A World Bank (2016) study of 118 countries over six years found that a 10 percent reduction in tax administration burden (as measured by the number of tax payments per year and time required to pay taxes) led to an increase in the number of incoming businesses by 3 percent per year. The analysis 
results indicate that the provision of investment incentives is considered adequate. It would be better to create a methodology or instrument to analyze the policy's effectiveness (Cedidlova, 2013). According to Sari, Dewi, \& Sun (2015), the Tax Holiday policy is considered to positively influence investment activities in Indonesia; however, Indonesia still has to prioritize improving infrastructure and bureaucracy.

The study conducted by Deng, Falvey dan Blake (2012) shows that the reform of the corporate income tax system impacts increasing the spillover productivity of FDI in the long run because it can help strengthen the existence of foreign investment. However, initially, it will cause a temporary decrease in the spillover productivity of FDI. Du, Harrison dan Jefferson (2014) analyzed tax subsidies to specific FDI business fields. The study results proved that the FDI business sectors with tax subsidies could produce higher productivity than those without tax subsidies. Countries in Asia use tax holidays as a tool to attract foreign investment, but it has different impacts on effective tax rates, depending on the capital allowance system they have (Suzuki, 2014).

The implementation of a policy should have goals to be achieved and policies in the form of incentives. The purpose of tax incentives should be planned and designed according to the objectives (Zolt, 2015). ). In Zolt's research, it is said that although economists have made much progress in determining the correlation between tax incentives and increased investment, it is difficult to determine which tax incentives increase investment. This may be due to the difficulty in calculating the marginal amount of investment associated with tax incentives, so it is suggested that the implementation of tax incentive policies has clear objectives. The provision of tax incentives in developing countries, which are supposed to attract foreign direct investment due to lower production costs, often has a poor design, lack of transparency, and complicated administration (Ugwu, 2018). ). Another problem that may arise from the application of tax incentives is raised by Daude, Gutierrez dan Melguizo (2017), who illustrates that the tax incentive mechanism can run the risk of making the tax system rigid and unstable, so the possibility of inefficiency is enormous. Therefore, tax incentive policies need to be reviewed and reformed according to each country's political and economic circumstances.

This study will use an investment incentive instrument in the form of a Tax Holiday to measure its effectiveness in attracting foreign investors and explicitly targets 18 pioneer 
Liza Herdiyati, Setyo Tri Wahyudi, Tax Holiday and Foreign Direct Investment In Indonesia.

industries. Several control variables are used to provide more relevant results that can influence foreign investment flows to a country, namely tax rates, inflation, currency exchange rates, market size, trade openness, availability of infrastructure, and wages. The observation period is for 15 years, from 2004 to 2018. The formulation of the problem in this study is whether Tax Holiday has a significant effect on FDI inflows in Indonesia? Based on the predetermined problem formulations, this research aims to analyze the effect of Tax Holiday on foreign investment inflows in Indonesia.

\section{THEORETICAL REVIEW}

Foreign Direct Investment (FDI) is an essential factor in growth and development. Developing countries' main objective in attracting foreign direct investment is to maximize investment opportunities by accumulating capital, which absorbs a lot of labor (Durham and Purrington 2011). The impact of FDI on a country's economy is generally related to increasing labor productivity through technology transfer and management and marketing skills that enable technological advancement and long-term economic growth (Boghean and State 2015).

Tax Holiday policy in Indonesia has been implemented since 2011 and is regulated in the Minister of Finance Regulation Number 130/PMK.011/2011 jo. Number 150/PMK.010/2018 regarding the Granting of Corporate Income Tax Reduction Facilities. Technical instructions regarding the implementation of Tax Holiday are regulated in Regulation of the Head of BKPM Number 12/2011 jo. Number 1/2019. In the final regulation regarding Tax Holiday, there are several expansions, including expanding the business sector by adding to the Digital Economic business sector, reducing tax rates to $50-100 \%$, and tax exemptions for 5-20 years. The industrial sectors that are targeted in the Tax Holiday consist of 18 industry pioneers. A pioneering industry is an industry that has broad linkages, provides added value and high externalities, introduces new technology, and has strategic value for the national economy (Kementerian Keuangan, 2018).

The pioneer industries that are the target of Tax Holiday (BKPM, 2019) are Upstream Base Metal Industry; Oil and Gas Refining or Refining Industry; Petrochemical Industry Based on Petroleum, Natural Gas and Coal; Organic Basic Chemical Industry; Inorganic Basic Chemical Industry: Main Pharmaceutical Raw Material Industry; Electromedical Equipment Manufacturing Industry; Industry for the manufacture of main components of electronic or telematic equipment; Machinery Manufacturing Industry and Main Machinery Components; Robotics Component Manufacturing Industry; Manufacture of Main 
Components of Power Plant Machinery; Motorized Vehicle Manufacturing Industry and Main Components of Motor Vehicles; Ship Component Manufacturing Industry; Railway Main Components Manufacturing Industry; Aircraft Main Components Manufacturing Industry; Agricultural, Plantation or Forestry Product Based Processing Industry; Economic Infrastructure; Digital Economy.

FDI occurs when investors build business operations in a foreign country (Chen et al., 2019). According to the Law of the Republic of Indonesia Number 25 (2007), ), FDI is an investment activity to conduct business in the Republic of Indonesia territory, which is carried out by foreign investors, either using foreign capital entirely or joining forces with domestic investors. In the investment law, the objectives of implementing investment include, among others, increasing national economic growth; creating jobs; promote sustainable economic development; increasing the competitiveness of the national business world; increase the capacity and capability of national technology; encourage the development of a people's economy; processing the potential economy into real economic strength by using funds originating from both domestic and foreign sources, and improve community welfare.

Various theories justify the critical position of FDI inflows in boosting economic growth and investors' returns in investing abroad. Experts in economic growth theory from the neoclassical era emphasized the importance of capital formation in economic growth (Ranis and Fei, 1961; Jorgenson, 1963). Neo-classical theorists were the first to describe the relationship between tax incentives and foreign capital's attractiveness in their efforts to carry out classical economic reforms (Munongo et al., 2017).

Capital arbitrage theory regarding the movement of foreign capital claims that differences in return rates can affect the movements of foreign capital, and investors act as arbitrators who determine the movements of capital to be invested (Yelpaala, 1985). Capital arbitrage theory identifies a robust causal relationship between tax incentives and FDI location determination (Munongo et al., 2017). Another theory that supports a positive relationship between tax incentives and FDI is the neoclassical investment theory developed by Jorgenson (1963). Neo-classical investment theory holds that businesses will continue to invest as long as the costs are less than the returns. The literature review conducted by Munongo et al. (2017) indicates that in neoclassical investment theory, tax incentives 
Liza Herdiyati, Setyo Tri Wahyudi, Tax Holiday and Foreign Direct Investment In Indonesia.

encourage existing companies' growth through reinvestment and attract new investment. Tax incentives are considered to reduce the cost of capital.

The New Economic Geography Theory (NEG Theory) explains the core area's concept and the periphery (core-periphery). It concludes that there is a direct positive relationship between reducing tax rates and an increase in investment (Parys and James, 2010). indicates that in neoclassical investment theory, tax incentives encourage existing companies' growth through reinvestment and attract new investment. Tax incentives are considered to reduce the cost of capital.

The New Economic Geography Theory (NEG Theory) explains the core area's concept and the periphery (core-periphery). It concludes that there is a direct positive relationship between reducing tax rates and an increase in investment. Munongo et al. (2017) assume that when the core is formed, there will be a risk of decreasing FDI's attractiveness in periphery areas. This is because foreign investors will prefer to invest in locations where there are already many businesses/companies, even though those areas have higher tax rates.

The most dominant theory among these hypotheses is the O-L-I Framework or Eclectic Theory, which explains the factors that motivate foreign investment, namely: ownership advantages, place advantages, and the internalization of multinational companies (MNEs) (Dunning 2001). O-L-I refers to Ownership, Location, and Internalization, three potential sources that determine a company's decision to become a multinational company. Ownership Advantage is a competitive advantage obtained by the owner or company when carrying out production activities abroad. Location Advantage explains the advantage of location factors, and internalization is an advantage related to cost or cost-efficiency. The OL-I Framework is synonymous with the factors that determine a person/company to invest abroad. Previous studies in the determinant sub-sector of PMA generally used macroeconomic variables, but regulatory changes are also essential to consider. Data from UNCTAD (2016) and World Bank (2016) show that the number of changes in PMA regulations that liberalize or support FDI inflows has exceeded the expected target.

In Boghean dan State (2015) research, PMA has several essential characteristics, namely: a long-term investment in foreign capital; aims to build new investments or purchase existing company assets; it can take the form of transfer of machinery, installations, equipment, measuring instruments, which contribute to an increase in fixed capital, and also skills in management and marketing; a large proportion of these transfers represent real (productive) capital, which allows the investor company to have the right to 
control, in whole or in part, the right to participate in decision-making, when its shares exceed $10 \%$ of total assets; the internal investment structure consists of a net contribution to capital, reinvested profits made from overseas subsidiaries, and loans made in local or international capital markets; the possibility of investors' companies to influence decisions, especially in terms of management effectiveness, subsidiaries or company branches located in other countries, where investors have long-term benefits.

Several studies on the impact of tax incentives on FDI in specific business fields have had different results. Olaleye, M. O., Riro, G. K., \& Memba (2016) researched the effect of reducing the income tax of foreign direct investment companies in the manufacturing business and proved a positive relationship between income tax incentives and PMA in the manufacturing sector. The analysis conducted by Amuka dan Ezeuka (2017) shows that tax incentive policies can change the inflow of FDI in the non-oil and gas industry. Reductions in corporate taxes in the mining, manufacturing, and service sectors also affect foreign investment in these sectors (Obeng 2014). In contrast to previous research, the results of a study conducted by Peters dan Kiabel (2015) show that the relationship between tax incentives and foreign direct investment flows is negative. It is recommended to re-evaluate the effect of tax incentives on the agricultural and manufacturing sectors separately.

\section{METHODS}

This research is quantitative descriptive research, which is research conducted to emphasize its analysis on numerical data (in the form of numbers), which is processed by specific statistical methods and interpreted in a description (Sugiyono, 2014). The step taken is observation in the form of available data and published by relevant sources and several reports, scientific journals, literature, and other sources that support and have a relationship with research studies. This research uses a multiple linear regression method with Ordinary Least Square (OLS), and the observation period is from 2004 to 2019. The test is carried out partially per business sector, and the regression model is required to meet the classical assumption test.

The variables used in the study include: Dependent The variable is the inflow of FDI in Indonesia (data source: BKPM); Independent Variable or Independent Variable is Tax 
Liza Herdiyati, Setyo Tri Wahyudi, Tax Holiday and Foreign Direct Investment In Indonesia.

Holiday, measured using a dummy variable. Value 1 for the period before Tax Holiday implementation, namely 2004-2010, and value 2 for the period during Tax Holiday implementation, namely 2011-2018 (data source: BKPM).

This study uses control variables in the form of factors that influence foreign investment flows, namely: Tax Rate, which is the percentage of tax imposed on companies. In the form of taxes on income and profits (percentage of revenue) in Indonesia (data source: World Bank); Inflation to show the rate of change in prices in the economy as a whole and is measured by the annual GDP implicit deflator (the ratio of GDP in current local currency to GDP in local currency is constant) (data source: World Bank); Market Size, which is measured as the percentage of annual growth in GDP per capita based on constant local currency, where GDP per capita is the gross domestic product divided by the population at mid-year (data source: World Bank); and Trade Openness, which is measured by the percentage of total exports and imports as a share of gross domestic product (data source: World Bank).

The research model is as follows:

$$
F D I_{i, t}=\beta_{0}+\beta_{1} T H_{t}+\beta_{2} T R_{t}+\beta_{3} I_{t}+\beta_{4} M S_{t}+\beta_{5} T O_{t}
$$

Where FDI: FDI Inflows, TH: Tax Holiday, TR: Tax Rate, I: Inflation, MS: Market Size, TO: Trade Openness, $\beta_{0,1, \ldots}$ : Coefficient, $\varepsilon$ : Error Term, i: Pioneer Industries, $t$. Time Period (2003 - 2019).

\section{RESULTS AND DISCUSSION}

The estimation model for each business sector is the focus of the research. For each model, it is known that tax holidays have a different effect on FDI inflows for each business sector. Models in the primary metal industry show the positive effect of the tax holiday on FDI, Coal Products Industry and Petroleum Refining, Pharmaceutical Industry, Chemical, and Traditional Medicines Products, Computer Industry, Electronic and Optical Goods, Electrical Equipment Industry; Machinery and Equipment Industry (not included in the others), Mining Supporting Service Activities; Rubber Industry, Rubber and Plastics Products; Motor Vehicle Industry, Trailer and Semi-Trailer; Other Transportation Equipment Industry; Repair and Installation of Machinery and Equipment; Procurement of electricity, gas, steam / hot water, and cold air; Civil Building Construction, and Information Service Activities. Meanwhile, the 
tax holiday's negative effect on FDI inflows was shown by the business sector in the Chemical Materials and Products Industry and the Paper and Paper Products Industry.

Based on data processing, the model estimation results for nine business fields are as follows:

Table 1. Estimation Model

\begin{tabular}{|c|c|c|}
\hline 1 & Base Metal Industry & $\mathrm{FDI}=3.88+3.38 * \mathrm{TH}+2.81 * \mathrm{TR}-0.06 * \mathrm{INF}+0.18 * \mathrm{MS}-0.76 * \mathrm{TO}$ \\
\hline 2 & $\begin{array}{l}\text { Coal Product Industry and } \\
\text { Petroleum Refinery }\end{array}$ & $\mathrm{FDI}=-91.71+8.72 * \mathrm{TH}+11.52 * \mathrm{TR}-0.68 * \mathrm{INF}+17.10 * \mathrm{MS}+8.23 * \mathrm{TO}$ \\
\hline 3 & $\begin{array}{l}\text { Chemical and Chemical } \\
\text { Products Industry } \\
\text { Pharmaceutical Industry, } \\
\text { Chemical Medicinal Products } \\
\text { and Traditional Medicines }\end{array}$ & $\mathrm{FDI}=4.34-0.34 * \mathrm{TH}+1.81 * \mathrm{TR}-0.75 * \mathrm{INF}+1.41 * \mathrm{MS}+0.62 * \mathrm{TO}$ \\
\hline 4 & $\begin{array}{l}\text { Computer, Electronic and } \\
\text { Optical Goods Industry } \\
\text { Electrical Equipment } \\
\text { Industry; Machinery and } \\
\text { Equipment Industry (not } \\
\text { included in the others) }\end{array}$ & $\mathrm{FDI}=5.08+1.18 * \mathrm{TH}+1.72 * \mathrm{TR}-0.58 * \mathrm{INF}+1.39 * \mathrm{MS}-0.58 * \mathrm{TO}$ \\
\hline 5 & $\begin{array}{l}\text { Mining Supporting Service } \\
\text { Activities; Rubber Industry, } \\
\text { Rubber and Plastics } \\
\text { Products; Motor Vehicle } \\
\text { Industry, Trailer and Semi } \\
\text { Trailer; Other } \\
\text { Transportation Equipment } \\
\text { Industry; Repair and } \\
\text { Installation of Machinery } \\
\text { and Equipment; } \\
\text { Procurement of electricity, } \\
\text { gas, steam / hot water and } \\
\text { cold air; Civil Building } \\
\text { Construction }\end{array}$ & $\mathrm{FDI}=20.65+1.89 * \mathrm{TH}-2.12 * \mathrm{TR}+0.70 * \mathrm{INF}-0.46 * \mathrm{MS}-0.42 * \mathrm{TO}$ \\
\hline 6 & $\begin{array}{l}\text { Paper and Paper Products } \\
\text { Industry }\end{array}$ & $\mathrm{FDI}=16.23+1.98 * \mathrm{TH}-0.19 * \mathrm{TR}+0.67 * \mathrm{INF}+0.42 * \mathrm{MS}-1.29 * \mathrm{TO}$ \\
\hline 7 & $\begin{array}{l}\text { Information Service } \\
\text { Activities }\end{array}$ & $\mathrm{FDI}=22.24+2.26 * \mathrm{TH}+2.91 * \mathrm{TR}+4.07 * \mathrm{INF}-14.41 * \mathrm{MS}+5.57 * \mathrm{TO}$ \\
\hline 8 & Base Metal Industry & $\mathrm{FDI}=11.96-0.361 * \mathrm{TH}-0.44 * \mathrm{TR}-2.26 * \mathrm{INF}+2.54 * \mathrm{MS}+0.89 * \mathrm{TO}$ \\
\hline 9 & $\begin{array}{l}\text { Coal Product Industry and } \\
\text { Petroleum Refinery }\end{array}$ & $\mathrm{FDI}=-51.96+8.61 * \mathrm{TH}+7.21 * \mathrm{TR}-1.93 * \mathrm{INF}-9.21 * \mathrm{MS}+11.62 * \mathrm{TO}$ \\
\hline
\end{tabular}

Source: Data proceed, 2020

If the relationship is positive, if the value of the independent variable increases by one unit, then the value of FDI Inflows will increase by $\beta 1, \beta 2, \beta 3, \beta 4$, and $\beta 5$ one unit (consecutively) in each model. If the relationship is negative, then if the value of the 
Liza Herdiyati, Setyo Tri Wahyudi, Tax Holiday and Foreign Direct Investment In Indonesia.

independent variable increases by one unit, then the value of FDI Inflows will decrease by $\beta 1, \beta 2, \beta 3, \beta 4$, and $\beta 5$ one unit (sequentially) in each model.

Table 2. Regresion Estimation Result

\begin{tabular}{|c|c|c|c|c|c|}
\hline & Business Fields & $\begin{array}{l}\text { Prob. Of Tax } \\
\text { Holiday }\end{array}$ & R-Squared & F-Stat. or Prob. & Standard Error \\
\hline 1 & Base Metal Industry & significant & $93,22 \%$ & significant & valid \\
\hline 2 & $\begin{array}{l}\text { Coal Product Industry and Petroleum } \\
\text { Refinery }\end{array}$ & not significant & $70,61 \%$ & significant & valid \\
\hline 3 & $\begin{array}{l}\text { Chemical and Chemical Products } \\
\text { Industry Pharmaceutical Industry, } \\
\text { Chemical Medicinal Products and } \\
\text { Traditional Medicines }\end{array}$ & not significant & $40,86 \%$ & not significant & valid \\
\hline 4 & $\begin{array}{l}\text { Computer, Electronic and Optical Goods } \\
\text { Industry Electrical Equipment Industry; } \\
\text { Machinery and Equipment Industry (not } \\
\text { included in the others) }\end{array}$ & not significant & $61,62 \%$ & not significant & valid \\
\hline 5 & $\begin{array}{l}\text { Mining Supporting Service Activities; } \\
\text { Rubber Industry, Rubber and Plastics } \\
\text { Products; Motor Vehicle Industry, Trailer } \\
\text { and Semi Trailer; Other Transportation } \\
\text { Equipment Industry; Repair and } \\
\text { Installation of Machinery and } \\
\text { Equipment; Procurement of electricity, } \\
\text { gas, steam / hot water and cold air; Civil } \\
\text { Building Construction }\end{array}$ & not significant & $29,35 \%$ & not significant & tidak valid \\
\hline 6 & Paper and Paper Products Industry & significant & $78,90 \%$ & significant & valid \\
\hline 7 & Information Service Activities & significant & $90,26 \%$ & not significant & valid \\
\hline 8 & Base Metal Industry & not significant & $48,54 \%$ & significant & valid \\
\hline 9 & $\begin{array}{l}\text { Coal Product Industry and Petroleum } \\
\text { Refinery }\end{array}$ & significant & $83,30 \%$ & significant & valid \\
\hline
\end{tabular}

Source: Data proceed, 2020

Based on the table above, Tax Holiday has a significant influence on the Base Metal Industry, Electrical Equipment Industry; Machinery and Equipment Industry (not included in the others), Mining Supporting Service Activities; Rubber Industry, Rubber and Plastics Products; Motor Vehicle Industry, Trailer and Semi-Trailer; Other Transportation Equipment Industry; Repair and Installation of Machinery and Equipment; Procurement of electricity, gas, steam / hot water, and cold air; Civil Building Construction, and Information Service Activities. Meanwhile, in 5 other business sectors, Tax Holiday is considered to have no significant effect.

The research results prove that the O-L-I Framework's internalization benefits are quite influential as a determining factor for investors in investing. Internalization deals with benefits related to cost or cost-efficiency. The provision of tax incentives is considered to provide benefits in lower costs for foreign investment. The ease of exporting goods is one of 
the foreign investors' considerations in determining its location and selection. It is expected to have a positive sectoral relationship with FDI (Obeng,s 2014). Business fields considered to be export-oriented will be closely related to currency exchange rates. Therefore, the depreciation of the currency exchange rate can increase FDI inflows in export-oriented business sectors (Obeng, 2014). The primary metal industry, the chemical industry, and chemical products, rubber industry, and materials from rubber and plastics are three of the five industries that contribute positively to exports (Kemenperin, 2018). The provision of tax incentives can have a positive impact on increasing PMA in each business sector. However, other factors, such as the ease of exporting goods, can also have a strong influence on the development of FDI in specific business fields.

The R-Squared value shows the amount of the independent variable's contribution to the dependent variable, and the rest is contributed by other variables not included in the model. The R-Squared value in 4 business sectors shows a relatively large percentage, in line with the significance of the independent variable's influence on the dependent variable. F-Hit or Prob Value shows the significance of all independent variables on the dependent variable. In the Base Metal Industry, Coal Product Industry and Petroleum Refining, Paper and Paper Goods Industry and Information Service Activities, Tax Holiday, Tax Rate, Inflation, Market Size, and Trade Openness have a significant effect on FDI Inflows together. Meanwhile, in the other five business sectors, all independent variables do not significantly affect FDI Inflows together. The standard error value of the regression model is shown in the S.E. of Regression. Suppose the S.E. of Regression is smaller than the standard deviation value of the response variable indicated by S.D. Dependent Variable means that this regression model is valid as a predictor model.

Based on table 2, it can be seen that the S.E. of the regression in eight business sectors was smaller than S.D. Dependent Variable, so the regression model is valid as a predictor model. In the Computer, Electronic, and Optical Goods Industry, the standard error value is greater than the standard deviation value, so the regression model in this equation is invalid as a predictor model.

According to Brende (2014) in The Global Competitiveness Report, Indonesia is in the 50th position on The Global Competitiveness Index 4.0 2019 Rankings, down five 
Liza Herdiyati, Setyo Tri Wahyudi, Tax Holiday and Foreign Direct Investment In Indonesia.

rankings from the previous year and is far below Thailand, Malaysia, and Singapore, which are at 40, 27 and 1. Indonesia's strength in competitiveness lies in its Market Size and macroeconomic stability. Strengthening the culture of doing business, financial system stability, and adopting new technology have also occurred in the past year. The development of information and communication technology has changed how businesses operate. The Internet provides a new platform for delivering government information and services and new opportunities to increase the efficiency and transparency of public administration, register business licenses, register property, pay taxes, and conduct international trade. Data from the World Bank (2016), shows that from 189 countries reviewed, more than 80 percent (152 countries) use web-based applications to process export and import documents, 75 percent of countries register or credit bureaus using online platforms. More than 40 percent of countries allow businesses to pay taxes online.

The problems in increasing competitiveness in Indonesia are the low level of country development, quality of access, and increased innovation. Based on the Doing Business Report from the World Bank (2016), ), the Doing Business rankings' best performers are not those without regulations. Their governments have successfully implemented rules that facilitate interaction in the market without hindering the private sector's development. There are 20 countries with the best ranking in Doing Business, and it is confirmed that they have good scores in the Global Competitiveness Index and Transparency International's Corruption Perceptions Index. So, it can be said that the quality of the Government is critical in supporting FDI inflows.

\section{CONCLUSION}

From the 18 industrial sectors targeted by the Tax Holiday policy, nine industrial sectors were significantly affected, namely the Base Metal Industry, Electrical Equipment Industry; Machinery and Equipment Industry (not included in the others), Mining Supporting Service Activities; Rubber Industry, Rubber and Plastics Products; Motor Vehicle Industry, Trailer and Semi-Trailer; Other Transportation Equipment Industry; Repair and Installation of Machinery and Equipment; Procurement of electricity, gas, steam / hot water, and cold air; Civil Building Construction, and Information Service Activities. The estimation results indicate that the Tax Holiday policy can increase the amount of foreign investment in Indonesia. This study's results are by O-L-I Theory, which states that the motivation of foreign investors to invest, among others, are for-profit and cost-efficiency. Based on this theory, tax incentives can minimize costs so that company profits will be greater and cost- 
efficiency can be achieved. So, it can be concluded that Tax Holiday is quite effective in attracting foreign investors to invest in Indonesia. However, we need to note that the Tax Holiday is not achieving its target well. This can be seen from the number of industrial sectors affected by the Tax Holiday, which only reached approximately $50 \%$ of the target.

Therefore, it is essential to know other possibilities that cause weakness in Indonesia's competitiveness at a global level. Based on this, policymakers could consider evaluating the effectiveness of tax holidays against their industrial targets. They may prioritize and increase incentives for industrial sectors affected by the tax holiday policy. For industrial targets that are unlikely to make this incentive an attraction, other types of investment incentives that are more appropriate can be given. The government should also pay attention to other aspects that affect Indonesia's FDI, especially those related to increasing global competitiveness. Three things, namely the country's development, the quality of access, and innovation, can be the primary concerns this year for designing policies, regulations, and incentives to support the economy.

\section{REFERENCES}

Abille, A.B., Mpuure, D.M.-N., Wuni, I.Y. and Dadzie, P. 2020. Modelling the Synergy Between Fiscal Incentives and Foreign Direct Investment in Ghana. Journal of Economics and Development 22(2), pp. 325-334. doi: 10.1108/jed-01-2020-0006.

Amuka, J. and Ezeuka, F. 2017. Tax Incentives and the Flow of Foreign Direct Investment to Non-Oil Sector: Empirical. Asian Journal of Social Sciences and Management Studies 4(1), pp. 57-64. doi: 10.20448/journal.500/2017.4.1/500.1.57.64.

BKPM 2018. Realisasi Penanaman Modal PMDN-PMA Triwulan II Tahun 2019. Available at: https://www.bkpm.go.id/images/uploads/file_siaran_pers/Paparan_Indonesia_TW_IV__2017_Kepala.pdf.

BKPM 2019. Lampiran I Peraturan Badan Koordinasi Penanaman Modal Republik Indonesia Nomor 1 Tahun 2019. Lampiran Peraturan Kepala BKPM No. 1 Tahun 2019, pp. 24-54. 
Liza Herdiyati, Setyo Tri Wahyudi, Tax Holiday and Foreign Direct Investment In Indonesia.

Boghean, C. and State, M. 2015. The Relation between Foreign Direct Investments (FDI) and Labour Productivity in the European Union Countries. Procedia Economics and Finance 32(15), pp. 278-285. Available at: http://dx.doi.org/10.1016/S2212-5671(15)01392-1.

Brende, K.S.S.B. 2014. The Global Competitiveness Report. doi: ISBN-13: 978-92-95044-739.

Cedidlova, M. 2013. The Effectiveness of Investment Incentives in Certain Foreign Companies Operating in the Czech Republic. Journal of Competitiveness 5(1), pp. 108-120. doi: 10.7441/joc.2013.01.08.

Chen, D., Yu, X. and Zhang, Z. 2019. Foreign Direct Investment Comovement and Home Country Institutions. Journal of Business Research 95(October 2018), pp. 220-231. Available at: https://doi.org/10.1016/j.jbusres.2018.10.023.

Daude, C., Gutierrez, H. and Melguizo, A. 2017. Doctoring the Ball: The Political Economy of Tax Incentives for Investment in the Dominican Republic. Journal of Economic Studies 44(1), pp. 2-23. doi: 10.1108/JES-05-2015-0090.

Deng, Z., Falvey, R. and Blake, A. 2012. Trading Market Access for Technology? Tax Incentives, Foreign Direct Investment and Productivity Spillovers in China. Journal of Policy Modeling 34(5), pp. 675-690. Available at:

http://dx.doi.org/10.1016/j.jpolmod.2012.01.003.

Du, L., Harrison, A. and Jefferson, G. 2014. FDI Spillovers and Industrial Policy: The Role of Tariffs and Tax Holidays. World Development 64(0519902), pp. 366-383. Available at: http://dx.doi.org/10.1016/j.worlddev.2014.06.005.

Dunning, J. 2001. The Eclectic (OLI) Paradigm of International Production: Past, Present and Future. International Journal of the Economics of Business 8, pp. 173-190. doi: 10.1080/13571510110051441.

Durham, F. and Purrington, R.D. 2011. Foreign Direct Investments in Asia. doi: 10.7312/durh91198-002.

Jorgenson, D.W. 1963. Capital Theory and Investment Behavior. American Economic Review 53(2), pp. 247-259. 
Kemenperin 2018. Kemenperin_Kemenperin Prioritaskan Industri Berorientasi Ekspor. Available at: https://kemenperin.go.id/artikel/18739/Kemenperin-Prioritaskan-IndustriBerorientasi-Ekspor.

Kementerian Keuangan 2018. Peraturan Menteri Keuangan No. 150/PMK.010/2018., pp. 110.

Kok, R. and Ersoy, B.A. 2009. Analyses of FDI determinants in developing countries.

International Journal of Social Economics 36(1-2), pp. 105-123. doi:

$10.1108 / 03068290910921226$.

Munongo, S., Akanbi, O.A. and Robinson, Z. 2017. Do Tax Incentives Matter for Investment? A Literature Review. Business and Economic Horizons 13(2), pp. 152-168. doi:

10.15208/beh.2017.12.

Obeng, C.K. 2014. Munich Personal RePEc Archive Effect of corporate tax on sector specific foreign direct investment in Ghana Effect of corporate tax on sector specific foreign direct investment in Ghana. Munich Personal RePEC Archive (58454)

Olaleye, M. O., Riro, G. K., \& Memba, F.S. 2016. Effect of Reduced Company Income Tax Incentives on Foreign Direct Investment in Listed Nigerian Manufacturing Companies. European Journal of Business, Economics and Accountancy 4(1), p. 39. Available at: www.idpublications.org.

Parys, S. and James, S. 2010. The Effectiveness of Tax Incentives in Attracting Investment: Panel Data Evidence from the CFA Franc Zone. International Tax and Public Finance 17, pp. 400-429. doi: 10.1007/s10797-010-9140-1.

Peters, G.T. and Kiabel, B.D. 2015. Tax Incentives and Foreign Direct Investment in Nigeria. IOSR Journal od Economics and Finance 6(5), pp. 10-20. doi:

10.1080/13504851.2018.1495817.

Presiden Republik Indonesia 2007. Undang-undang No. 25 Tahun 2007. Bank Indonesia (235), p. 245. 
Liza Herdiyati, Setyo Tri Wahyudi, Tax Holiday and Foreign Direct Investment In Indonesia.

Ranis, G. and Fei, J.C.H. 1961. A Theory of Economic Development. American Economic Review 51(4), pp. 553-565. doi: 10.1257/aer.98.5.i.

Saini, N. and Singhania, M. 2018. Determinants of FDI in developed and developing countries: a quantitative analysis using GMM. doi: 10.1108/JES-07-2016-0138.

Sari, N., Dewi, M.S. and Sun, Y. 2015. Indonesia: The Effect of Tax Holiday on Economic Growth Related to Foreign Investment. Procedia - Social and Behavioral Sciences 211, pp. 1008-1015. doi: 10.1016/j.sbspro.2015.11.134.

Sugiyono 2014. Metode Penelitian Kuantitatif, Kualitatif dan R\&D. Bandung: Penerbit Alfabeta.

Suzuki, M. 2014. Corporate Effective Tax Rates in Asian Countries. Japan and the World Economy 29, pp. 1-17. Available at: http://dx.doi.org/10.1016/j.japwor.2013.11.001.

Ugwu, J.I. 2018. Tax Incentives and Foreign Direct Investment. (September), pp. 30-52. UNCTAD 2000. Tax Incentives and Foreign Direct Investment: A Global Survey. ASIT Advisory Study (16)

UNCTAD 2016. World Investment Report 2016: Investor Nationality: Policy Challenges. Geneva.

UNCTAD 2019. World Investment Report 2019. Special Economic Zones., p. 4. Available at: https://unctad.org/en/PublicationsLibrary/wir2019_en.pdf.

World Bank 2016. Doing Business 2016: Measuring Regulatory Quality and Efficiency. Washington DC. doi: 10.1596/978-1-4648-0667-4.

World Bank 2018. Unemployment, total (\% of total labor force) (modeled ILO estimate). Yelpaala, K. 1985. In Search of Effective Policies for Foreign Direct Investment: Alternatives to Tax Incentive Policies In Search of Effective Policies for Foreign Direct Investment: Alternatives to Tax. 7(2)

Zolt, E. 2015. Tax Incentives: Protecting the tax base. Paper for Workshop on Tax Incentives and Base Protection New York, 23-24 April 2015 (April), pp. 23-24. 